\title{
Detection of Somatic Mutations in Gastroenteropancreatic Neuroendocrine Tumors Using Targeted Deep Sequencing
}

\author{
SAMUEL BACKMAN ${ }^{1}$, OLOV NORLÉN ${ }^{1}$, BARBRO ERIKSSON ${ }^{2}$, \\ BRITT SKOGSEID ${ }^{2}$, PETER STÅLBERG ${ }^{1}$ and JOAKIM CRONA ${ }^{1}$ \\ Department of ${ }^{1}$ Surgical and ${ }^{2}$ Medical Sciences, Uppsala University, Uppsala, Sweden
}

\begin{abstract}
Mutations affecting the mechanistic target of rapamycin (MTOR) signalling pathway are frequent in human cancer and have been identified in up to $15 \%$ of pancreatic neuroendocrine tumours (NETS). Grade A evidence supports the efficacy of MTOR inhibition with everolimus in pancreatic NETs. Although a significant proportion of patients experience disease stabilization, only a minority will show objective tumour responses. It has been proposed that genomic mutations resulting in activation of MTOR signalling could be used to predict sensitivity to everolimus. Patients and Methods: Patients with NETs that underwent treatment with everolimus at our Institution were identified and those with available tumour tissue were selected for further analysis. Targeted next-generation sequencing (NGS) was used to re-sequence 22 genes that were selected on the basis of documented involvement in the MTOR signalling pathway or in the tumourigenesis of gastroenterpancreatic NETs. Radiological responses were documented using Response Evaluation Criteria in Solid Tumours. Results: Six patients were identified, one had a partial response and four had stable disease. Sequencing of tumour tissue resulted in a median sequence depth of 667.1 (range $=404-1301$ ) with 1-fold coverage of 95.9-96.5\% and 10-fold coverage of 87.6-92.2\%. A total of 494 genetic variants were discovered, four of which were identified as pathogenic. All pathogenic variants were validated using Sanger sequencing and were found exclusively in menin 1 (MENI) and death domain associated protein (DAXX) genes. No mutations in the MTOR pathway-related genes were observed. Conclusion: Targeted NGS is a feasible method with high diagnostic yield for genetic characterization of pancreatic NETs. A potential association between mutations
\end{abstract}

Correspondence to: Joakim Crona, MD, Ph.D, Department of Surgical Sciences, Akademiska sjukhuset ing 70, FOA2, 75185, Uppsala, Sweden. Tel: +46 186110000, Fax: +46 186114911, e-mail: joakim.crona@surgsci.uu.se

Key Words: MTOR, biomarker, PNET, next-generation sequencing. in NETs and response to everolimus should be investigated by future studies.

Aberrant activation of the mechanistic target of rapamycin (MTOR) pathway has been identified in multiple different cancer types (1) and may occur as a result from both loss of function [phosphatase and tensin homolog (PTEN), tuberous sclerosis 1 (TSC1) and TSC2 and gain of function [phosphatidylinositol-4,5-bisphosphate 3-kinase catalytic subunit alpha (PIK3CA), MTOR mutations $(2,3)$. Inhibitors of the MTOR signalling complex (rapalogues), such as everolimus, have shown clinical benefit in a variety of cancer types, including renal and breast carcinomas, as well as neuroendocrine tumours (NETs) of pancreatic origin (4-7).

Gastroenteropancreatic NETs are relatively rare tumours, and the majority of patients show advanced disease stage upon diagnosis $(8,9)$. The treatment arsenal for metastatic disease includes somatostatin analogues, alkylating chemotherapy and signalling pathway inhibitors (4, 10-12). Grade A evidence supports the antitumor effect of the rapalogue everolimus in pancreatic NETs $(4,13)$. Although a majority of patients with pancreatic NET in the RADIANT 3 trial experienced disease stabilization, only 5\% had a significant tumour reduction (4). Everolimus is also approved by the US Food and Drug Administration for treatment of non-functional lung and gastrointestinal NETs following results from the RADIANT 4 trial (14). In order to avoid administration of a less effective treatment associated with significant morbidity, efficient biomarkers capable of predicting NET sensitivity to everolimus are being sought. Recent studies in vitro have shown that reduced phosphorylation of the MTOR complex can predict resistance to everolimus in bronchial NETs (15). Furthermore, high-throughput sequencing studies of epithelial cancer have revealed that somatic mutations in genes associated with MTOR signalling can confer sensitivity to everolimus therapy (16-18). Iyer et al. sequenced the exomes of bladder carcinomas and identified TSC1 mutations exclusively in responders to everolimus therapy (16). Wagle et al. utilized a different approach and 
sequenced tumours from exceptional rapalogue responders, revealing an activating $M T O R$ mutation in a patient with metastatic urothelial carcinoma (17).

While the majority of pancreatic NETs have mutations in chromatin-modulating genes [menin 1 (MENI) and death domain-associated protein $(D A X X)$ and chromatin remodeler $(A T R X)$ genes], about $15 \%$ also harbour mutations in genes involved in MTOR signalling (19-22). This was different from SI NETs, in which the only significantly mutated gene was cyclin-dependent kinase inhibitor 1B $(C D K N 1 B)$, involved in cell-cycle regulation (23). There was no significant association with mutations in genes related to the MTOR pathway in small intestinal (SI) NETs (23-25). We analyzed tumour specimens from patients with NET treated with everolimus for mutations in disease-specific and MTOR pathway genes.

\section{Patients and Methods}

Patients and tissues. This was a retrospective study of patients treated at the Department of Endocrine Surgery that included biomaterial from Uppsala Biobank, Endocrine tumour collection (Ethical approval 00-128/3.15.2000). The study was approved by the local Ethical Committee (dnr no. 2011/375 and 2012/160). Writteninformed consent was obtained from the individual patients. All patients were above 18 years of age at the time of inclusion. Frozen tumour tissue from patients with histopathologically confirmed NET who had been treated with everolimus $(n=6)$ were identified. Cryosections were obtained and analysed with haematoxylin and eosin stain to confirm a tumour cell content of $>50 \%$. Characteristics of the included patients are outlined in Table I.

Response criteria. Responses to therapy were evaluated using Response Evaluation Criteria In Solid Tumours (RECIST) 1.1 Criteria. Briefly, the computed tomographic/magnetic resonance images after therapy were compared to those at baseline and rated as: complete response, with a disappearance of all lesions; partial response if the longest diameter of index lesions decreased by $\geq 30 \%$; progressive disease if the longest diameter of target lesions increased by $\geq 20 \%$; and stable disease if the sum of index lesions was between these parameters (26).

DNA extraction. Genomic DNA was extracted from fresh frozen tissue samples using DNeasy Blood \& Tissue Kit (Qiagen, Hilden, Germany) as previously described (27). DNA quality and concentrations were assessed using a Nanodrop spectrophotometer (ThermoFischer Scientific, Waltham, MA, USA) as well as a Qubit flourometer (Invitrogen, Carlsbad, CA, USA). Inclusion criteria for library preparation were a $260 / 280 \mathrm{~nm}$ spectrum ratio of $>1.8$ and double-stranded DNA concentration above $5 \mathrm{ng} / \mu \mathrm{l}$.

Targeted genomic capture. A Truseq Custom Amplicon (Illumina Inc, San Diego, CA, USA) targeted capture and paired end library kit was designed using Illumina Design Studio (Version 2012-12-01; http://designstudio.illumina.com). Targeted genes were selected on the basis of documented involvement in (i) gastroenteropancreatic NET tumourigenesis or (ii) AKT-MTOR signalling pathway. In total 22 genes were included: MTOR, GTPase NRas (NRAS; exons 2, 3 and 4), endothelial PAS domain protein 1 (EPAS1), von HippelLindau disease tumour suppressor (VHL), PIK3CA (codons 545, 1047), catenin beta 1 (CTNNB1; exons 3 and 5), KIT proto-oncogene receptor tyrosine kinase (KIT; exons $9,11,13,17)$, rapamycininsensitive companion of MTOR (RICTOR), fibroblast growth factor receptor 4 (FGFR4; codon 388), DAXX, serine/threonine-protein kinase B-raf (BRAF; codon 600), epidermal growth factor receptor (EGFR; codons 18-21), TSC1, PTEN, MEN1, GTPase HRAS (HRAS; (exons 2-4), GTPase KRAS (KRAS; exons 2-4), RAC-alpha serine/threonine-protein kinase (AKT1; codon 17), transcriptional repressor protein YY1 (YY1; codon 372), TSC2, regulatoryassociated protein of MTOR complex 1 (RPTOR) and cellular tumour antigen p53 (TP53). Full details are presented in Table II. In order to be able to detect variants causing alternative splicing in tumour-suppressor genes, coordinates were extended with a padding of 10 base pairs at intron-exon boundaries. Coordinates were obtained from the human reference sequence HG19 and the cumulative target size was 52040 base pairs. The final TruSeq Custom Amplicon design constituted 672 amplicons having a median size of 175 bases. The in silico amplicon coverage was $>98 \%$ with a total gap distance of 827 bases located in regions with homologous sequences: RPTOR exon 6, MEN1 exon 2 and TP53 exon 6.

Library preparation and MiSEQ sequencing. Library preparation and sequencing was performed at the university core facility (http://molmed.medsci.uu.se/SNP+SEQ+Technology+Platform/) as detailed in the MiSEQ System user guide for Reagent Kit v2. Targeted enrichment and library preparation were performed from $250 \mathrm{ng}$ of double-stranded DNA (Illumina Inc.) according to the manufacturer's instructions. Briefly, upstream and downstream oligonucleotides were hybridized to genomic DNA followed by an extension-ligation process that connected the hybridized upstream and downstream oligonucleotides using a DNA ligase. Extensionligation fragments were amplified by polymerase chain reaction (PCR) and connected to index adaptor sequences to allow for sample multiplexing using the TruSeq Custom Amplicon Index Kit (Illumina Inc.). The PCR product was purified using AMPure XP beads (Beckman Coulter Inc, Carlsbad, CA, USA). To confirm successful library preparation selected test samples were separated and visualized on a $4 \%$ agarose gel. Each library sample underwent quantity normalization and all six samples were pooled together with 88 samples of other origin into a single suspension. The generated paired end libraries were subjected to a single sequencing using an Illumina MiSEQ instrument (Illumina Inc.). Generated sequences were demultiplexed by Illumina MiSEQ reporter 2.1.43 software and the results written to FASTQ files.

Bioinformatic analysis. A manifest file detailing the sequence of the hybridizing oligonucleotides as well as the coordinates of designed amplicons was downloaded from the manufacturer and uploaded into the MiSEQ reporter 2.1.43 software as instructed. Briefly, the sequencing reads were aligned to the reference sequence (human reference sequence HG19) by the SmithWaterman algorithm using default settings. Variant calling was performed using a variant caller from the Genome Analysis Toolkit using default settings (28). The generated .BAM files were imported into CLC Genomics Workbench 5.51 (Qiagen, Aarhus, Denmark) and quality control analysis was performed. The generated .VCF files were filtered and annotated in CLC Genomics Workbench, synonymous variants without a probable splice site 
Table I. Clinical characteristics of included patients.

\begin{tabular}{|c|c|c|c|c|c|c|c|c|c|c|}
\hline $\begin{array}{l}\text { Patient } \\
\text { number }\end{array}$ & Gender & $\begin{array}{l}\text { Age at } \\
\text { diagnosis, } \\
\text { years }\end{array}$ & $\begin{array}{l}\text { Histopatho- } \\
\text { logical } \\
\text { diagnosis }\end{array}$ & $\begin{array}{c}\mathrm{Ki}^{6} 67^{+}, \\
\%\end{array}$ & , Staging* & $\begin{array}{l}\text { Genetic } \\
\text { syndrome }\end{array}$ & $\begin{array}{c}\text { Sample } \\
\text { localization }\end{array}$ & $\begin{array}{c}\text { Duration of } \\
\text { everolimus, } \\
\text { months }\end{array}$ & $\begin{array}{l}\text { Discontinued } \\
\text { due to }\end{array}$ & $\begin{array}{c}\text { Best } \\
\text { response }\end{array}$ \\
\hline 1 & Male & 40 & PNET & 4 & IV & No & Primary tumour & 14 & Side-effects & Stable disease \\
\hline 2 & Female & 40 & PNET & 1 & IV & No & Lymph node metastasis & 8 & Progressive disease & Partial response \\
\hline 3 & Male & 43 & PNET & & IV & No & Liver metastasis & 83 (ongoing) & - & Stable disease \\
\hline 4 & Male & 46 & SINET & 2 & IV & No & Omental metastasis & 3 & Side-effects & Stable disease \\
\hline 5 & Male & 71 & SINET & 1 & IV & No & Primary tumour & 10 & Side-effects & Stable disease \\
\hline 6 & Female & 59 & SINET & 1 & IV & No & Liver metastasis & 3 & \multicolumn{2}{|c|}{ Progressive disease Progressive disease } \\
\hline
\end{tabular}

PNET, Pancreatic neuroendocrine tumour; SINET, small intestinal neuroendocrine tumour. *According to European Neuroendocrine Tumor Society criteria $(44,45)$.

Table II. Genes included for DNA enrichment. For particular genes with documented hotspot codons, only particular segments were targeted.

\begin{tabular}{|c|c|c|c|c|c|}
\hline Gene & Encoded protein & Chromosome & Exons, $\mathrm{n}$ & Amplicons, $\mathrm{n}$ & Selected fragments \\
\hline MTOR & Serine/threonine-protein kinase MTOR & 1 & 58 & 123 & \\
\hline$N R A S$ & GTPase NRas & 1 & 3 & 5 & Codons $12,13,61$ \\
\hline EPAS1 & Endothelial PAS domain-containing protein 1 & 2 & 16 & 37 & \\
\hline$V H L$ & von Hippel-Lindau disease tumor suppressor & 3 & 3 & 10 & \\
\hline$P I K 3 C A$ & $\begin{array}{c}\text { Phosphatidylinositol-4,5-bisphosphate 3-kinase } \\
\text { catalytic subunit alpha isoform }\end{array}$ & 3 & 2 & 5 & Codons 545, 1047 \\
\hline CTNNB1 & Catenin beta- 1 & 3 & 2 & 6 & Exons $3 \& 5$ \\
\hline KIT & KIT proto-oncogene receptor tyrosine kinase & 4 & 2 & 8 & Exons $9,11,13,17$ \\
\hline RICTOR & Rapamycin-insensitive companion of mTOR & 5 & 39 & 82 & \\
\hline FGFR4 & Fibroblast growth factor receptor 4 & 5 & 1 & 3 & Codon 388 \\
\hline$D A X X$ & Death domain-associated protein 6 & 6 & 8 & 34 & \\
\hline$B R A F$ & Serine/threonine-protein kinase B-raf & 7 & 1 & 1 & Codon 600 \\
\hline$E G F R$ & Epidermal growth factor receptor & 7 & 4 & 13 & Exons $18,19,20,21$ \\
\hline TSC1 & Tuberous sclerosis 1 (hamartin) & 9 & 23 & 53 & \\
\hline PTEN & $\begin{array}{c}\text { Phosphatidylinositol 3,4,5-trisphosphate 3-phosphatase and } \\
\text { dual-specificity protein phosphatase PTEN }\end{array}$ & 10 & 9 & 61 & \\
\hline MEN1 & Menin & 11 & 10 & 35 & \\
\hline$H R A S$ & GTPase HRas proto-oncogene & 11 & 3 & 8 & Codons $12,13,61$ \\
\hline$K R A S$ & GTPase KRas proto-oncogene & 12 & 3 & 5 & Codons $12,13,61$ \\
\hline$A K T 1$ & RAC-alpha serine/threonine-protein kinase & 14 & 1 & 2 & Codon 17 \\
\hline$Y Y 1$ & Transcriptional repressor protein YY1 & 14 & 1 & 2 & Codon 372 \\
\hline TSC2 & Tuberous sclerosis 2 (tuberin) & 16 & 42 & 91 & \\
\hline RPTOR & Regulatory-associated protein of MTOR complex 1 & 17 & 34 & 63 & \\
\hline TP53 & Cellular tumour antigen p53 & 17 & 11 & 25 & \\
\hline
\end{tabular}

effect were removed and the remaining variants were annotated for overlapping information in publicly available databases; Single Nucleotide Polymorphism database (dbSNP) build 137, Catalogue of Somatic Mutations in Cancer (29), database of Human Gene Mutation Data (30) and Leiden Open (source) Variant Database. The impact of non-synonymous amino acid substitution was assessed in silico using Polymorphism Phenotyping v2 (31) and Sorting Intolerant from Tolerant (32). Variant annotations were integrated to classify variants as pathogenic, variant of unknown significance (VUS) or polymorphism and selected entries were validated with Sanger sequencing. Primer sequences can be obtained upon request.
Sanger sequencing. Fragments corresponding to pathogenic variants discovered by NGS were amplified by PCR and sequenced using Sanger sequencing. $C D K N 1 B$ had previously been re-sequenced in the included SI NETs without finding any pathogenic variants (33).

\section{Results}

Cohort characteristics. Samples from six patients with welldifferentiated NETs were included; three originated from the small intestine and three from the pancreas. All patients had NET stage 4 at diagnosis and those with available Ki67 
Table III. Read mapping. Quantity of generated reads as well as general and specific read coverage.

Fold coverage at targeted regions, $\%$

\begin{tabular}{|c|c|c|c|c|c|c|c|}
\hline \multirow[b]{2}{*}{ Patient number } & \multirow[b]{2}{*}{ No. of sequence reads } & \multirow[b]{2}{*}{ Specificity to targeted regions, $\%$} & \multirow[b]{2}{*}{ Mean read coverage } & \\
\hline & & & & $1 \times$ & $10 \times$ & $40 \times$ & $80 \times$ \\
\hline 1 & 845998 & 67.18 & 667.1 & 96.54 & 95.06 & 93.04 & 91.93 \\
\hline 2 & 809662 & 65.2 & 612.4 & 96.32 & 95.09 & 93.38 & 91.66 \\
\hline 3 & 848380 & 68 & 666.5 & 96.54 & 95.46 & 93.04 & 90.62 \\
\hline 4 & 950698 & 72.08 & 803.4 & 96.53 & 94.84 & 91.6 & 87.64 \\
\hline 5 & 873216 & 68.37 & 697.2 & 95.93 & 95.34 & 92.47 & 90.03 \\
\hline 6 & 1604126 & 67.15 & 1269.7 & 96.06 & 95.44 & 94.82 & 92.16 \\
\hline
\end{tabular}

Table IV. Variant calling. Generated variants and results remaining after filtering.

\begin{tabular}{|c|c|c|c|c|c|c|c|c|}
\hline \multirow[b]{2}{*}{$\begin{array}{l}\text { Patient } \\
\text { number }\end{array}$} & \multirow[b]{2}{*}{$\begin{array}{l}\text { Discovered } \\
\text { variants }\end{array}$} & \multirow[b]{2}{*}{ SNV } & \multirow[b]{2}{*}{ INDEL } & \multirow[b]{2}{*}{$\begin{array}{l}\text { \#1 Targeted } \\
\text { genes }\end{array}$} & \multicolumn{4}{|c|}{ Variants remaining after filtering steps } \\
\hline & & & & & $\begin{array}{l}\text { \#2 Significant } \\
\text { mutations }\end{array}$ & $\begin{array}{l}\text { \#3 Discard } \\
\text { common SNPs }\end{array}$ & $\begin{array}{l}\text { \#4 Quality } \\
\text { filter }\end{array}$ & $\begin{array}{l}\text { \#5 Redundancy } \\
\text { filter }\end{array}$ \\
\hline 1 & 85 & 65 & 20 & 80 & 8 & 5 & 3 & 3 \\
\hline 2 & 92 & 67 & 25 & 86 & 11 & 7 & 2 & 2 \\
\hline 3 & 83 & 57 & 26 & 77 & 6 & 2 & 1 & 1 \\
\hline 4 & 79 & 59 & 20 & 72 & 8 & 3 & 1 & 1 \\
\hline 5 & 83 & 61 & 22 & 76 & 6 & 2 & 1 & 1 \\
\hline 6 & 72 & 53 & 19 & 66 & 6 & 2 & 2 & 2 \\
\hline
\end{tabular}

SNV: Single nucleotide variants; INDEL: insertion or deletion; SNP: single nucleotide polymorphism.

measurements had been classified as World Health Organisation grade 1 or 2 . The included specimens had been sampled from primary tumours $(n=2)$ or distant metastases $(n=4)$.

Response to everolimus. Time on therapy ranged from 3 to 83 months. Three of the patients discontinued their therapy due to side-effects and two due to disease progression (Table I). One patient showed a partial response and four had stable disease. Patient 3 experienced durable disease stabilization that is ongoing at 83 months.

Sequence coverage. A median of 860798 (range 809662 to 1604126) paired end reads were generated. Sequence read mapping showed a median specificity of $67.6 \%$ (range $65.2-$ $72,1 \%$ ) to the bases targeted by enrichment. The median coverage at the targeted bases was 667.1 (range=404-1301). A total of $95.9-96.6 \%$ of bases had a coverage of at least 1fold, while $94.8-95.5 \%$ had a coverage of at least 10 -fold and $87.6-92.2 \%$ of bases had a coverage of at least 80 -fold. Detailed sequencing statistics are presented in Table III.

Discovered genetic variants. Variant calling generated a total of 494 genetic variants; there were 362 single nucleotide variants and 132 insertions/deletions (Table IV). In order to identify possibly pathogenic variants, a series of stringent filtering steps were applied. After filtering a total of four variants were identified as pathogenic and six were classified as VUS. All pathogenic variants were successfully validated by Sanger sequencing (Figure 1). Pathogenic variants were detected exclusively in NETs of pancreatic origin: MEN1 c.1724_1735delTCAACTCGAGCG, p.Ile575_ Ala579delins Thr in patient 1, MEN1 c.1486G>T, p.Glu496* in patient 2 (Figure 2). In the tumour of patient 3 , there were two pathogenic mutations detected: MEN1 c.1189G $>$ T, p.Glu397* and DAXX c.1622_1623insT, p.Ser541fs. Due to the absence of DNA from non-tumoural tissues, we were unable to determine whether these variants were somatic or occurred in the germline.

Performance and throughput time. Following optimization of the bioinformatic workflow, the theoretical throughput time for the executed assays was 7 days. This was divided to 1 day for sample preparation and quality assessment, 2 days for sample enrichment and multiplexing, 1 day for MiSEQ sequencing, as well as 1 day for bioinformatics processing and interpretation. Validation of the generated results with Sanger sequencing may be estimated to require an additional 7-14 days depending on the complexity of the 


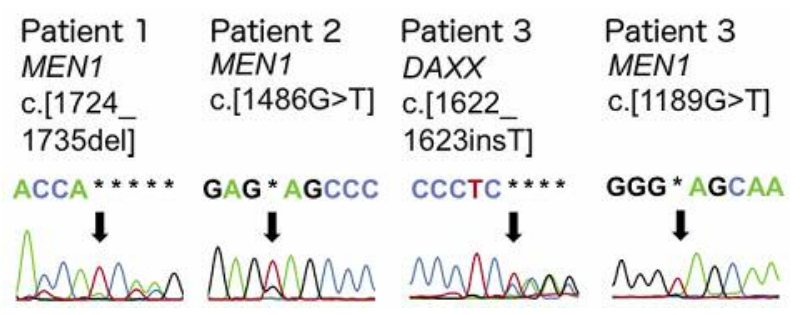

Figure 1. Chromatograms from validation of the detected pathogenic mutations.

specific fragment. The total reagent cost of the executed assays including quality control, library preparation, multiplexing and sequencing was 84 USD per sample. This excluded the non-recurring costs of hardware and software.

\section{Discussion}

We report successful validation of a targeted deep sequencing workflow for the sequencing of genes associated with pancreatic NET pathogenesis and mTOR signalling. The method showed a high diagnostic yield and was able to validate previous mutational findings observed in PNETs. Since we were unable to detect any clinically actionable mutations, the limited material does not allow us to draw any conclusion regarding the potential impact of such screening in clinical practice.

Theoretically, a relatively high sequence depth should improve detection of genetic variants with low allelic frequency. Our samples had $92-95 \%$ of the targeted regions covered by at least 80 sequencing reads, theoretically this should allow for near-perfect sensitivity for genetic variants with low allelic frequency (0.2) (34). A similar pipeline for library preparation, sequencing and bioinformatic processing was previously validated as having near-perfect sensitivity in NETs of other origin, further supporting the robustness of the results here (35). This is in line with the current literature maintaining that targeted NGS has a higher yield and lower cost than traditional methods (35-37). Although targeted NGS has been shown to be an effective method for resequencing of formalin-fixed paraffin-embedded tissues, no such conclusions can be drawn from this study as it exclusively analysed frozen tumour material.

Accumulating evidence supports the use of mutations within MTOR pathway genes in order to predict response to MTOR inhibitors $(17,18,38-40)$. Everolimus is an oral allosteric inhibitor of MTOR approved for use in patients with pancreatic NETs. Although disease stabilization was achieved in a high proportion of patients with progressive disease in the RADIANT 3 trial, radiological response was seen only in a minority of patients (4). Furthermore, a large proportion of
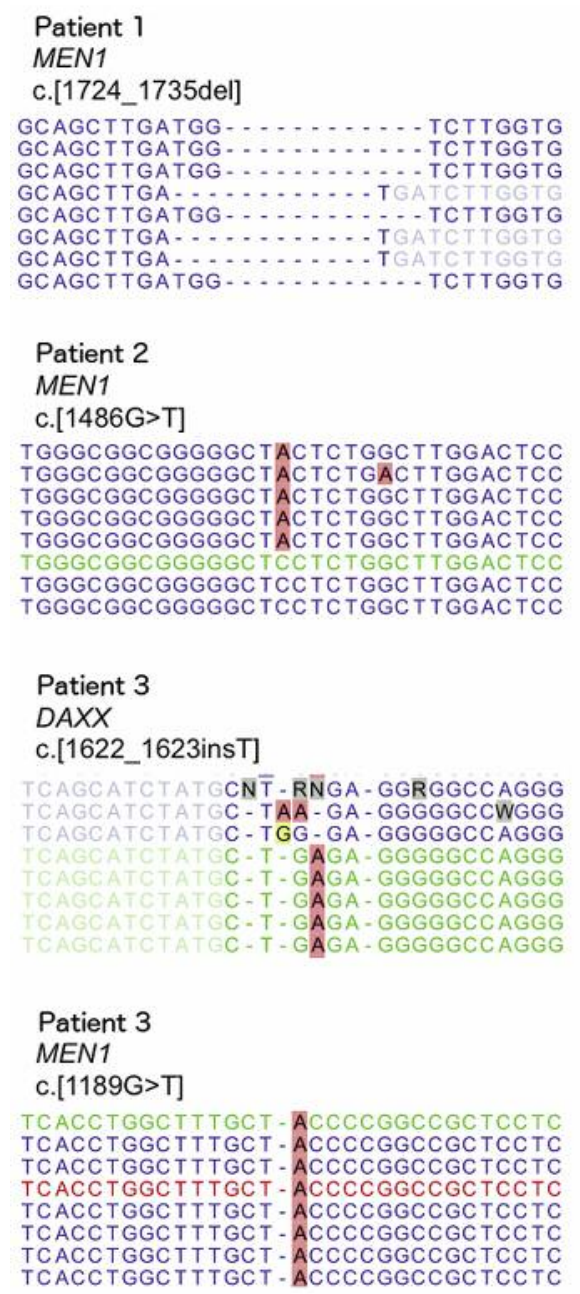

Figure 2. Representative screenshots from CLC Genomics Workbench 5.01 revealing read mappings at the corresponding locations of the pathogenic mutations.

patients experienced severe toxicities. In order to identify those with a high likelihood of clinical response to rapalogue treatment, clinical and molecular biomarkers are needed.

We were able to detect pathogenic $D A X X$ and MEN1 mutations in NETs of pancreatic origin. There were no pathogenic mutations discovered in the analy $\zeta$ ed SI NET tumours. Subsequent to the design of this study, large genomewide sequencing studies have revealed that SI NETs lack mutations in the loci that were targeted by this study $(23,25)$.

Only two patients in this study showed a satisfactory response, with one partial response and one durable disease stabilization, similar to the real-life experience of everolimus treatment in NETs. There were no mutations in MTOR pathway genes. Larger studies such as SEQTOR (NCT02246127) may provide more definitive answers to whether mutations in MTOR pathway genes could have a predictive role in patients with 
pancreatic NETs. In patient 3, who has ongoing disease stabilization of 83 months, as well as a decrease in glucagon secretion with consequent relief of related symptoms, targeted NGS detected mutations within the MEN1 and DAXX genes. Mutations in $D A X X$ have been shown to cause an alternative lengthening of telomeres (ALT) phenotype $(19,20)$ enabling replicative immortality. It has been shown that ALT mutations render sensitivity to ATR inhibitors (41). Whether ALT-deficient tumours are particularly sensitive to MTOR inhibition would of interest to investigate in further studies.

It has been demonstrated that NETs may exhibit both inter- and intratumoural genetic heterogeneity, at both the level of single nucleotide variations (33) and copy number variations (42). Similarly to the current clinical practice, we investigated one sample per patient. Consequently genetic heterogeneity could be a source of error for this study, as is the case for clinical testing in general. One approach to overcoming this may be to sequence DNA derived from plasma in order to find variants of prognostic importance in circulating tumour DNA (43).

To conclude, this study shows that targeted NGS is a feasible method for genomic characterization of pancreatic NETs. There were no mutations in mTOR pathway-related genes, neither in the patient with a partial response, nor in those with stable disease. Given the low patient number $(n=6)$ with mixed radiological responses, our material does not allow us to draw any further conclusions regarding a potential association between everolimus response and somatic mutations in NETs.

\section{Conflicts of Interest}

The Authors declare no conflicts of interest

\section{Acknowledgements}

Dr. Peyman Björklund and Professor Per Hellman contributed generously with intellectual and logistical support to this study. Library preparation and sequencing was performed by Science for Life Laboratories, Uppsala node, Uppsala, Sweden. This study was funded by a grant to JC from Lions Cancerforskningsfond, Uppsala Sweden. The Authors are grateful to the contributing patients.

\section{References}

1 Wander SA, Hennessy BT and Slingerland JM: Next-generation mTOR inhibitors in clinical oncology: How pathway complexity informs therapeutic strategy. J Clin Invest 121: 1231-1241, 2011.

2 Grabiner BC, Nardi V, Birsoy K, Possemato R, Shen K, Sinha S, Jordan A, Beck AH and Sabatini DM: A diverse array of cancer-associated MTOR mutations are hyperactivating and can predict rapamycin sensitivity. Cancer Discov 4: 554-563, 2014.

3 Zoncu R, Efeyan A and Sabatini DM: mTOR: from growth signal integration to cancer, diabetes and ageing. Nat Rev Mol Cell Biol 12: 21-35, 2011
4 Yao JC, Shah MH, Ito T, Bohas CL, Wolin EM, Van Cutsem E, Hobday TJ, Okusaka T, Capdevila J, de Vries EG, Tomassetti P, Pavel ME, Hoosen S, Haas T, Lincy J, Lebwohl D and Oberg K: Everolimus for advanced pancreatic neuroendocrine tumors. $\mathrm{N}$ Engl J Med 364: 514-523, 2011.

5 Baselga J, Campone M, Piccart M, Burris HA, 3rd, Rugo HS, Sahmoud T, Noguchi S, Gnant M, Pritchard KI, Lebrun F, Beck JT, Ito Y, Yardley D, Deleu I, Perez A, Bachelot T, Vittori L, Xu Z, Mukhopadhyay P, Lebwohl D and Hortobagyi GN: Everolimus in postmenopausal hormone-receptor-positive advanced breast cancer. N Engl J Med 366: 520-529, 2012.

6 Krueger DA, Care MM, Holland K, Agricola K, Tudor C, Mangeshkar P, Wilson KA, Byars A, Sahmoud T and Franz DN: Everolimus for subependymal giant-cell astrocytomas in tuberous sclerosis. N Engl J Med 363: 1801-1811, 2010.

7 Yao JC, Lombard-Bohas C, Baudin E, Kvols LK, Rougier P, Ruszniewski P, Hoosen S, St Peter J, Haas T, Lebwohl D, Van Cutsem E, Kulke MH, Hobday TJ, O'Dorisio TM, Shah MH, Cadiot G, Luppi G, Posey JA and Wiedenmann B: Daily oral everolimus activity in patients with metastatic pancreatic neuroendocrine tumors after failure of cytotoxic chemotherapy: a phase II trial. J Clin Oncol 28: 69-76, 2010.

8 Ekeblad S, Skogseid B, Dunder K, Oberg K and Eriksson B: Prognostic factors and survival in 324 patients with pancreatic endocrine tumor treated at a single institution. Clin Cancer Res 14: 7798-7803, 2008.

9 Strosberg J, Gardner N and Kvols L: Survival and prognostic factor analysis in patients with metastatic pancreatic endocrine carcinomas. Pancreas 38: 255-258, 2009.

10 Moertel CG, Hanley JA and Johnson LA: Streptozocin alone compared with streptozocin plus fluorouracil in the treatment of advanced islet-cell carcinoma. N Engl J Med 303: 1189-1194, 1980.

11 Caplin ME, Pavel M, Cwikla JB, Phan AT, Raderer M, Sedlackova E, Cadiot G, Wolin EM, Capdevila J, Wall L, Rindi G, Langley A, Martinez S, Blumberg J and Ruszniewski P: Lanreotide in metastatic enteropancreatic neuroendocrine tumors. N Engl J Med 371: 224-233, 2014.

12 Raymond E, Dahan L, Raoul JL, Bang YJ, Borbath I, LombardBohas C, Valle J, Metrakos P, Smith D, Vinik A, Chen JS, Horsch D, Hammel P, Wiedenmann B, Van Cutsem E, Patyna S, Lu DR, Blanckmeister C, Chao R and Ruszniewski P: Sunitinib malate for the treatment of pancreatic neuroendocrine tumors. $\mathrm{N}$ Engl J Med 364: 501-513, 2011.

13 Pavel ME, Hainsworth JD, Baudin E, Peeters M, Horsch D, Winkler RE, Klimovsky J, Lebwohl D, Jehl V, Wolin EM, Oberg $\mathrm{K}$, Van Cutsem E and Yao JC: Everolimus plus octreotide longacting repeatable for the treatment of advanced neuroendocrine tumours associated with carcinoid syndrome (RADIANT-2): a randomised, placebo-controlled, phase 3 study. Lancet 378: 2005-2012, 2011.

14 Yao JC, Fazio N, Singh S, Buzzoni R, Carnaghi C, Wolin E, Tomasek J, Raderer M, Lahner H, Voi M, Pacaud LB, Rouyrre N, Sachs C, Valle JW, Delle Fave G, Van Cutsem E, Tesselaar M, Shimada Y, Oh DY, Strosberg J, Kulke MH and Pavel ME: Everolimus for the treatment of advanced, non-functional neuroendocrine tumours of the lung or gastrointestinal tract (RADIANT-4): a randomised, placebo-controlled, phase 3 study. Lancet 387: 968-977, 2016.

15 Gagliano T, Bellio M, Gentilin E, Mole D, Tagliati F, Schiavon M, Cavallesco NG, Andriolo LG, Ambrosio MR, Rea F, Degli 
Uberti E and Zatelli MC: mTOR, p70S6K, AKT, and ERK1/2 levels predict sensitivity to mTOR and PI3K/mTOR inhibitors in human bronchial carcinoids. Endocr Relat Cancer 20: 463475,2013

16 Iyer G, Hanrahan AJ, Milowsky MI, Al-Ahmadie H, Scott SN, Janakiraman M, Pirun M, Sander C, Socci ND, Ostrovnaya I, Viale A, Heguy A, Peng L, Chan TA, Bochner B, Bajorin DF, Berger MF, Taylor BS and Solit DB: Genome sequencing identifies a basis for everolimus sensitivity. Science 338: 221, 2012.

17 Wagle N, Grabiner BC, Van Allen EM, Hodis E, Jacobus S, Supko JG, Stewart M, Choueiri TK, Gandhi L, Cleary JM, Elfiky AA, Taplin ME, Stack EC, Signoretti S, Loda M, Shapiro GI, Sabatini DM, Lander ES, Gabriel SB, Kantoff PW, Garraway LA and Rosenberg JE: Activating MTOR mutations in a patient with an extraordinary response on a phase I trial of everolimus and pazopanib. Cancer discovery 4: 546-553, 2014.

18 Wagle N, Grabiner BC, Van Allen EM, Amin-Mansour A, Taylor-Weiner A, Rosenberg M, Gray N, Barletta JA, Guo Y, Swanson SJ, Ruan DT, Hanna GJ, Haddad RI, Getz G, Kwiatkowski DJ, Carter SL, Sabatini DM, Janne PA, Garraway LA and Lorch JH: Response and acquired resistance to everolimus in anaplastic thyroid cancer. N Engl $\mathrm{J}$ Med 371: 1426-1433, 2014

19 Jiao Y, Shi C, Edil BH, de Wilde RF, Klimstra DS, Maitra A, Schulick RD, Tang LH, Wolfgang CL, Choti MA, Velculescu VE, Diaz LA Jr., Vogelstein B, Kinzler KW, Hruban RH and Papadopoulos N: DAXX/ATRX, MEN1, and mTOR pathway genes are frequently altered in pancreatic neuroendocrine tumors. Science 331: 1199-1203, 2011

20 Marinoni I, Kurrer AS, Vassella E, Dettmer M, Rudolph T, Banz V, Hunger F, Pasquinelli S, Speel EJ and Perren A: Loss of DAXX and ATRX are associated with chromosome instability and reduced survival of patients with pancreatic neuroendocrine tumors. Gastroenterology 146: 453-460.e455, 2014.

21 Sadanandam A, Wullschleger S, Lyssiotis CA, Grotzinger C, Barbi S, Bersani S, Korner J, Wafy I, Mafficini A, Lawlor RT, Simbolo M, Asara JM, Blaker H, Cantley LC, Wiedenmann B, Scarpa A and Hanahan D: A cross-species analysis in pancreatic neuroendocrine tumors reveals molecular subtypes with distinctive clinical, metastatic, developmental, and metabolic characteristics. Cancer discovery 5: 1296-1313, 2015

22 Yuan F, Shi M, Ji J, Shi H, Zhou C, Yu Y, Liu B, Zhu Z and Zhang J: KRAS and DAXX/ATRX gene mutations are correlated with the clinicopathological features, advanced diseases, and poor prognosis in Chinese patients with pancreatic neuroendocrine tumors. Int J Biol Sci 10: 957-965, 2014.

23 Francis JM, Kiezun A, Ramos AH, Serra S, Pedamallu CS, Qian ZR, Banck MS, Kanwar R, Kulkarni AA, Karpathakis A, Manzo V, Contractor T, Philips J, Nickerson E, Pho N, Hooshmand SM, Brais LK, Lawrence MS, Pugh T, McKenna A, Sivachenko A, Cibulskis K, Carter SL, Ojesina AI, Freeman S, Jones RT, Voet D, Saksena G, Auclair D, Onofrio R, Shefler E, Sougnez C, Grimsby J, Green L, Lennon N, Meyer T, Caplin M, Chung DC, Beutler AS, Ogino S, Thirlwell C, Shivdasani R, Asa SL, Harris CR, Getz G, Kulke M and Meyerson M: Somatic mutation of $C D K N 1 B$ in small intestine neuroendocrine tumors. Nat Genet 45: 1483-1486, 2013.

24 Lawrence MS, Stojanov P, Mermel CH, Robinson JT, Garraway LA, Golub TR, Meyerson M, Gabriel SB, Lander ES and Getz
G: Discovery and saturation analysis of cancer genes across 21 tumour types. Nature 505: 495-501, 2014.

25 Banck MS, Kanwar R, Kulkarni AA, Boora GK, Metge F, Kipp BR, Zhang L, Thorland EC, Minn KT, Tentu R, Eckloff BW, Wieben ED, Wu Y, Cunningham JM, Nagorney DM, Gilbert JA, Ames MM and Beutler AS: The genomic landscape of small intestine neuroendocrine tumors. J Clin Invest 123: 2502-2508, 2013.

26 Eisenhauer EA, Therasse P, Bogaerts J, Schwartz LH, Sargent D, Ford R, Dancey J, Arbuck S, Gwyther S, Mooney M, Rubinstein L, Shankar L, Dodd L, Kaplan R, Lacombe D, Verweij J. New response evaluation criteria in solid tumours: revised RECIST guideline (version 1.1). Eur J Cance 45: 22847, 2008.

27 Åkerstrom T, Crona J, Delgado Verdugo A, Starker LF, Cupisti K, Willenberg HS, Knoefel WT, Saeger W, Feller A, Ip J, Soon P, Anlauf M, Alesina PF, Schmid KW, Decaussin M, Levillain P, Wangberg B, Peix JL, Robinson B, Zedenius J, Backdahl M, Caramuta S, Iwen KA, Botling J, Stålberg P, Kraimps JL, Dralle H, Hellman P, Sidhu S, Westin G, Lehnert H, Walz MK, Åkerstrom G, Carling T, Choi M, Lifton RP and Björklund P: Comprehensive re-sequencing of adrenal aldosterone producing lesions reveal three somatic mutations near the KCNJ5 potassium channel selectivity filter. PLoS One 7: e41926, 2012.

28 McKenna A, Hanna M, Banks E, Sivachenko A, Cibulskis K, Kernytsky A, Garimella K, Altshuler D, Gabriel S, Daly M and DePristo MA: The Genome Analysis Toolkit: a MapReduce framework for analyzing next-generation DNA sequencing data. Genome Res 20: 1297-1303, 2010.

29 SA, Bindal N, Bamford S, Cole C, Kok CY, Beare D, Jia M, Shepherd R, Leung K, Menzies A, Teague JW, Campbell PJ, Stratton MR and Futreal PA: COSMIC: Mining complete cancer genomes in the Catalogue of Somatic Mutations in Cancer. Nucleic Acids Res 39: D945-950, 2011.

30 Stenson PD, Ball EV, Mort M, Phillips AD, Shiel JA, Thomas NS, Abeysinghe S, Krawczak M and Cooper DN: Human Gene Mutation Database (HGMD): 2003 update. Hum Mutat 21: 577$581,2003$.

31 Adzhubei IA, Schmidt S, Peshkin L, Ramensky VE, Gerasimova A, Bork P, Kondrashov AS and Sunyaev SR: A method and server for predicting damaging missense mutations. Nat Methods 7: 248-249, 2010.

32 Kumar P, Henikoff S and Ng PC: Predicting the effects of coding non-synonymous variants on protein function using the SIFT algorithm. Nat Protoc 4: 1073-1081, 2009.

33 Crona J, Gustavsson T, Norlen O, Edfeldt K, Akerstrom T, Westin G, Hellman P, Bjorklund P and Stalberg P: Somatic mutations and genetic heterogeneity at the $C D K N 1 B$ locus in small intestinal neuroendocrine tumors. Ann Surg Oncol 22(Suppl 3): S1428-1435, 2015.

34 Cibulskis K, Lawrence MS, Carter SL, Sivachenko A, Jaffe D, Sougnez C, Gabriel S, Meyerson M, Lander ES and Getz G: Sensitive detection of somatic point mutations in impure and heterogeneous cancer samples. Nat Biotech 31: 213-219, 2013.

35 Welander J, Andreasson A, Juhlin CC, Wiseman RW, Backdahl M, Hoog A, Larsson C, Gimm O and Soderkvist P: Rare germline mutations identified by targeted next-generation sequencing of susceptibility genes in pheochromocytoma and paraganglioma. J Clin Endocrinol Metab 99: E1352-1360, 2014. 
36 Simbolo M, Mian C, Barollo S, Fassan M, Mafficini A, Neves D, Scardoni M, Pennelli G, Rugge M, Pelizzo MR, Cavedon E, Fugazzola L and Scarpa A: High-throughput mutation profiling improves diagnostic stratification of sporadic medullary thyroid carcinomas. Virchows Arch 465: 73-78, 2014.

37 Grossmann V, Roller A, Klein HU, Weissmann S, Kern W, Haferlach C, Dugas M, Haferlach T, Schnittger S and Kohlmann A: Robustness of amplicon deep sequencing underlines its utility in clinical applications. J Mol Diagn 15: 473-484, 2013.

38 Bissler JJ, McCormack FX, Young LR, Elwing JM, Chuck G, Leonard JM, Schmithorst VJ, Laor T, Brody AS, Bean J, Salisbury S and Franz DN: Sirolimus for angiomyolipoma in tuberous sclerosis complex or lymphangioleiomyomatosis. N Engl J Med 358: 140-151, 2008.

39 Davies DM, de Vries PJ, Johnson SR, McCartney DL, Cox JA, Serra AL, Watson PC, Howe CJ, Doyle T, Pointon K, Cross JJ, Tattersfield AE, Kingswood JC and Sampson JR: Sirolimus therapy for angiomyolipoma in tuberous sclerosis and sporadic lymphangioleiomyomatosis: a phase 2 trial. Clin Cancer Res 17: 4071-4081, 2011.

40 Wagner AJ, Malinowska-Kolodziej I, Morgan JA, Qin W, Fletcher CD, Vena N, Ligon AH, Antonescu CR, Ramaiya NH, Demetri GD, Kwiatkowski DJ and Maki RG: Clinical activity of mTOR inhibition with sirolimus in malignant perivascular epithelioid cell tumors: targeting the pathogenic activation of mTORC1 in tumors. J Clin Oncol 28: 835-840, 2010.

41 Flynn RL, Cox KE, Jeitany M, Wakimoto H, Bryll AR, Ganem NJ, Bersani F, Pineda JR, Suva ML, Benes CH, Haber DA, Boussin FD and Zou L: Alternative lengthening of telomeres renders cancer cells hypersensitive to ATR inhibitors. Science 347: 273-277, 2015.
42 Hessman O, Skogseid B, Westin G and Åkerström G: Multiple allelic deletions and intratumoral genetic heterogeneity in MEN1 pancreatic tumors. J Clin Endocrinol Metab 86: 1355-1361, 2001.

43 Diehl F, Schmidt K, Choti MA, Romans K, Goodman S, Li M, Thornton K, Agrawal N, Sokoll L, Szabo SA, Kinzler KW, Vogelstein B and Diaz LA Jr.: Circulating mutant DNA to assess tumor dynamics. Nat Med 15: 985-900, 2008.

44 Rindi G, Kloppel G, Alhman H, Caplin M, Couvelard A, de Herder WW, Erikssson B, Falchetti A, Falconi M, Komminoth P, Korner M, Lopes JM, McNicol AM, Nilsson O, Perren A, Scarpa A, Scoazec JY and Wiedenmann B: TNM staging of foregut (neuro)endocrine tumors: a consensus proposal including a grading system. Virchows Arch 449: 395-401, 2006.

45 Rindi G, Kloppel G, Couvelard A, Komminoth P, Korner M, Lopes JM, McNicol AM, Nilsson O, Perren A, Scarpa A, Scoazec JY and Wiedenmann B: TNM staging of midgut and hindgut (neuro) endocrine tumors: a consensus proposal including a grading system. Virchows Archiv 451: 757-762, 2007.
Received October 15, 2016

Revised December 14, 2016

Accepted December 15, 2016 